\title{
Colletoic Acid, a Novel 11 $\beta$-Hydroxysteroid Dehydrogenase Type 1 Inhibitor from Colletotrichum gloeosporioides SANK 21404
}

\author{
Azusa Aoyagi, Mariko Ito-Kobayashi, Yasunori Ono, Yoji Furukawa, Mizuki Takahashi, \\ Yasunori Muramatsu, Megumi Umetani, Toshio Takatsu
}

Received: February 22, 2008/Accepted: February 28, 2008

(C) Japan Antibiotics Research Association

\begin{abstract}
Colletoic acid, a novel $11 \beta$-hydroxysteroid dehydrogenase type 1 (11 $\beta$-HSD1) inhibitor, was found and isolated from the cultured broth of the producing fungus Colletotrichum gloeosporioides SANK 21404. Its structure was determined to be a novel acorene-type sesquiterpene by several spectroscopic methods. The absolute structure of colletoic acid was established using a modified Mosher's method and single-crystal X-ray diffraction analysis.
\end{abstract}

Keywords colletoic acid, 11 $\beta$-HSD1 inhibitor, Colletotrichum gloeosporioides, taxonomy, fermentation, isolation, structure

\section{Introduction}

$11 \beta$-Hydroxysteroid dehydrogenase type 1 (11 $\beta$-HSD1) intracellularly converts inert glucocorticoid (11dehydrocorticosterone in rats and mice, cortisone in humans) into active glucocorticoid (corticosterone in rats and mice, cortisol in humans) in vivo. As glucocorticoids oppose the insulin effect, several studies on mice lacking [1] or overexpressing [2] $11 \beta$-HSD1 reported that $11 \beta$ HSD1 plays an important role in Type 2 diabetes and metabolic syndrome.

Our preceding paper described the discovery of novel

T. Takatsu (Corresponding author), A. Aoyagi, Y. Ono, Y. Furukawa, M. Takahashi: Advanced Technology Research Laboratories, Daiichi Sankyo Co., Ltd., 1-2-58 Hiromachi, Shinagawa-ku, Tokyo 140-8710, Japan,

E-mail: takatsu.toshio.c2@daiichisankyo.co.jp
$11 \beta$-HSD1 inhibitors named sterenin A, B, C and D [3]. Here, we report the discovery of a novel $11 \beta$-HSD1 inhibitor, colletoic acid (Fig. 1), produced by a fungus identified as Colletotrichum gloeosporioides SANK 21404.

\section{Materials and Methods}

\section{General}

The ${ }^{1} \mathrm{H}$ - and ${ }^{13} \mathrm{C}-\mathrm{NMR}$ spectra were recorded at $298 \mathrm{~K}$ on an AVANCE 500 spectrometer equipped with a cryogenic probe (Bruker BioSpin) operating at $500 \mathrm{MHz}$ and 125 $\mathrm{MHz}$, respectively. The samples for NMR characterization were dissolved in DMSO- $d_{6}$ or $\mathrm{CDCl}_{3}$. The optical rotation and IR spectrum were measured with a DIP-370 (JASCO) and a VALOR-III (JASCO), respectively. The mass

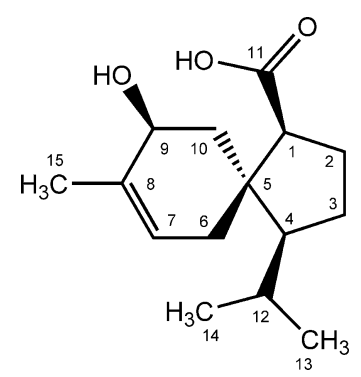

Fig. 1 Structure of colletoic acid.

M. Ito-Kobayashi: Exploratory Research Laboratories II, Daiichi Sankyo Co., Ltd., 1-16-13 Kitakasai, Edogawa-ku, Tokyo 1348630, Japan

Y. Muramatsu, M. Umetani: Exploratory Research Laboratories I, Daiichi Sankyo Co., Ltd., 1-16-13 Kitakasai, Edogawa-ku, Tokyo 134-8630, Japan 
spectrum and high-resolution mass spectrum were measured with a JMS700QV Mstation (JEOL). The HPLC analysis was carried out with an HP1100 system (Agilent). All measurements of the X-ray crystallographic analysis were made on a Rigaku RAXIS RAPID imaging plate area detector with graphite monochromated $\mathrm{Cu}-\mathrm{K} \alpha$ radiation at a temperature of $-100 \pm 1^{\circ} \mathrm{C}$.

\section{Detection of Colletoic Acid}

The progress of purification was monitored by HPLC (column; Capcell pak C18 UG120, 4.6×250 mm, mobile phase; $\mathrm{CH}_{3} \mathrm{CN}-\mathrm{H}_{2} \mathrm{O}(45: 55)$ containing $0.05 \% \mathrm{HCOOH}$, flow rate; $1.0 \mathrm{ml} /$ minute, detection; $\mathrm{UV}$ at $210 \mathrm{~nm}$, retention time; 7.9 minutes).

\section{Esterification of Colletoic Acid}

Colletoic acid $(60 \mathrm{mg})$ was dissolved in methanol $(1.5 \mathrm{ml})$ and trimethylsilyl (TMS)-diazomethane $(0.8 \mathrm{ml})$ was added. After 5 hours at room temperature, the reaction mixture was applied to a preparative HPLC (column; Capcell pak $\mathrm{C} 18 \mathrm{UG} 120,20 \times 250 \mathrm{~mm}$, mobile phase; $\mathrm{CH}_{3} \mathrm{CN}$ $\mathrm{H}_{2} \mathrm{O}(65: 35)$ containing $0.05 \% \mathrm{HCOOH}$, flow rate; $10 \mathrm{ml} /$ minute, detection; UV at $210 \mathrm{~nm})$. The collected fraction was evaporated under reduced pressure to remove the $\mathrm{CH}_{3} \mathrm{CN}$ followed by freeze drying to give pure colletoic acid methylester $(34.3 \mathrm{mg})$.

\section{Colletoic Acid Methylester}

${ }^{1} \mathrm{H}-\mathrm{NMR}$ (DMSO- $d_{6}$, the remaining DMSO signal was used for an internal standard as $\left.\delta_{\mathrm{H}} 2.50\right) ; 0.78(\mathrm{H}-14,3 \mathrm{H}$, d, $J=6.6 \mathrm{~Hz}), 0.85(\mathrm{H}-13,3 \mathrm{H}, \mathrm{d}, J=6.8 \mathrm{~Hz}), 1.53(\mathrm{H}-4,1 \mathrm{H}$, m), $1.62(\mathrm{H}-3,2 \mathrm{H}, \mathrm{m}), 1.63$ (H-15, 3H, br. s), 1.71 (H-2, $1 \mathrm{H}, \mathrm{m}), 1.72(\mathrm{H}-10,1 \mathrm{H}, \mathrm{m}), 1.74(\mathrm{H}-12,1 \mathrm{H}, \mathrm{m}), 1.78(\mathrm{H}-2$, $1 \mathrm{H}, \mathrm{m}), 1.80$ (H-6, 1H, br. d), $1.86(\mathrm{H}-10,1 \mathrm{H}, \mathrm{m}), 1.88(\mathrm{H}-$ $6,1 \mathrm{H}$, br. d), $2.60(\mathrm{H}-1,1 \mathrm{H}, \mathrm{t}, J=8.1 \mathrm{~Hz}), 3.55\left(11-\mathrm{OCH}_{3}\right.$, $3 \mathrm{H}, \mathrm{s}), 3.98(\mathrm{H}-9,1 \mathrm{H}, \mathrm{m}), 4.56(9-\mathrm{OH}, 1 \mathrm{H}$, br. d, $J=5.9 \mathrm{~Hz}), 5.32$ (H-7, 1H, br. s).

\section{Preparation of MTPA Derivatives}

Colletoic acid methylester $(1.0 \mathrm{mg})$ was dissolved in pyridine $(1.0 \mathrm{ml})$, and $(R)-(-)$ - or $(S)-(+)-2-$ methoxy-2(trifluoromethyl)phenylacetyl chloride (MTPA-Cl, $150 \mu 1$ each) was added. After 14 hours at room temperature, each reaction mixture was applied to an HPLC (column; Senshu pak Pegasil ODS, $10 \times 250 \mathrm{~mm}$, mobile phase; $\mathrm{CH}_{3} \mathrm{CN}$ $\mathrm{H}_{2} \mathrm{O}(85: 15)$ containing $0.05 \% \mathrm{HCOOH}$, flow rate; $5.0 \mathrm{ml} /$ minute, detection; UV at $210 \mathrm{~nm}$ ). The collected fraction was evaporated under reduced pressure to remove the solvent, followed by freeze drying to give pure $(S)$ - or (R)-MTPA derivative of colletoic acid methylester $(800 \mu \mathrm{g}$ each).
(S)-MTPA Derivative of Colletoic Acid Methylester

${ }^{1} \mathrm{H}-\mathrm{NMR}\left(\mathrm{CDCl}_{3}\right.$, TMS was used for an internal standard as $\left.\delta_{\mathrm{H}} 0.00\right) ; 0.84(\mathrm{H}-14,3 \mathrm{H}, \mathrm{d}, J=6.5 \mathrm{~Hz}), 0.92(\mathrm{H}-13,3 \mathrm{H}$, d, $J=6.7 \mathrm{~Hz}), 1.44(\mathrm{H}-4,1 \mathrm{H}, \mathrm{m}), 1.56(\mathrm{H}-2,1 \mathrm{H}, \mathrm{m}), 1.65$ (H-15, 3H, br. s), 1.68 (H-3, 2H, m), $1.73(\mathrm{H}-12,1 \mathrm{H}, \mathrm{m})$, $1.76(\mathrm{H}-10,1 \mathrm{H}, \mathrm{m}), 1.79$ (H-2, 1H, m), 1.97 (H-6, 1H, br. d, $18 \mathrm{~Hz}$ ), 2.07 (H-6, 1H, br. d, $18 \mathrm{~Hz}), 2.17(\mathrm{H}-10,1 \mathrm{H}$, dd, $J=14.1,6.5 \mathrm{~Hz}), 2.46(\mathrm{H}-1,1 \mathrm{H}, \mathrm{dd}, J=8.9,6.2 \mathrm{~Hz}), 3.50$ $\left(11-\mathrm{OCH}_{3}, 3 \mathrm{H}, \mathrm{s}\right), 3.60\left(\mathrm{MTPA}^{-\mathrm{OCH}_{3}}, 3 \mathrm{H}, \mathrm{s}\right), 5.57$ (H-9, $1 \mathrm{H}$, br. t), 5.59 (H-7, 1H, br. s), 7.41 (MTPA-Ph, 3H), 7.57 (MTPA-Ph, 2H).

$(R)$-MTPA Derivative of Colletoic Acid Methylester

${ }^{1} \mathrm{H}-\mathrm{NMR}\left(\mathrm{CDCl}_{3}\right.$, TMS was used for an internal standard as $\left.\delta_{\mathrm{H}} 0.00\right) ; 0.85(\mathrm{H}-14,3 \mathrm{H}, \mathrm{d}, J=6.7 \mathrm{~Hz}),, 0.93(\mathrm{H}-13,3 \mathrm{H}$, d, $J=6.7 \mathrm{~Hz}), 1.45$ (H-15, 3H, br. s), $1.53(\mathrm{H}-4,1 \mathrm{H}, \mathrm{m})$, $1.69(\mathrm{H}-2,1 \mathrm{H}, \mathrm{m}), 1.70(\mathrm{H}-3,2 \mathrm{H}, \mathrm{m}), 1.74(\mathrm{H}-12,1 \mathrm{H}, \mathrm{m})$, $1.87(\mathrm{H}-2,1 \mathrm{H}, \mathrm{m}), 1.91(\mathrm{H}-10,1 \mathrm{H}, \mathrm{dd}, J=13.8,6.2 \mathrm{~Hz}$,$) ,$ 1.99 (H-6, 1H, br. d, $J=18 \mathrm{~Hz}), 2.06$ (H-6, 1H, br. d, $J=18 \mathrm{~Hz}), 2.21(\mathrm{H}-10,1 \mathrm{H}, \mathrm{dd}, J=13.8,6.5 \mathrm{~Hz}), 2.58$ (H-1, $1 \mathrm{H}$, br. t), $3.52\left(11-\mathrm{OCH}_{3}, 3 \mathrm{H}, \mathrm{s}\right), 3.59$ (MTPA-OCH 3 , $3 \mathrm{H}$, s), $5.55(\mathrm{H}-7,1 \mathrm{H}$, br. s), 5.61 (H-9, 1H, br. t), 7.41 (MTPA$\mathrm{Ph}, 3 \mathrm{H}), 7.58$ (MTPA-Ph, 2H).

\section{X-Ray Crystallographic Analysis}

A colorless block crystal of colletoic acid crystallized from hexane-EtOAc solution was mounted on a glass fiber. The crystal data are as follows: Space group $P 2{ }_{1} 22_{1}, a=10.521(6) \AA, b=10.842(8) \AA, c=25.32(2) \AA$, $V=2887(3) \AA^{3}, Z=8, D c=1.16 \mathrm{~g} / \mathrm{cm}^{3}$. The structure was determined by direct methods with the program SIR92 and refined by full-matrix least-squares methods based on $F$. The final $R$ and $R w$ values were 0.035 and 0.042 for $I>3.00(I)$ data, respectively. All calculations were performed using a CrystalStructure crystallographic software package (version 3.6.0, Rigaku/MSC).

\section{Biological Assays}

$11 \beta$-HSD1 reductase and $11 \beta$-HSD2 dehydrogenase inhibitory activities were evaluated by the method described in the preceding paper [3].

\section{Results}

\section{Taxonomy of the Producing Organism}

The producing microorganism, Colletotrichum gloeosporioides SANK 21404, was isolated from a leaf collected in Fukuoka Prefecture, Japan. Colonies on potato dextrose agar (PDA) was attained $82 \sim 88 \mathrm{~mm}$ in 7 days at $25^{\circ} \mathrm{C}$, and were greenish grey to white. The colonies were 


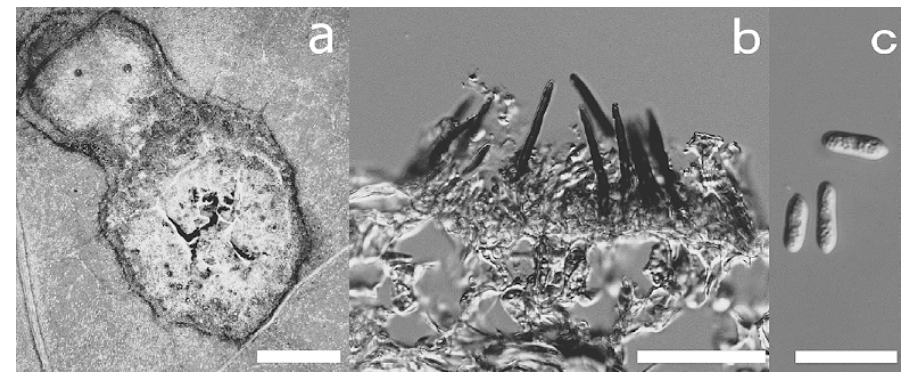

Fig. 2 Colletotrichum gloeosporioides SANK 21404.

a, Symptoms associated with Colletotrichum gloeosporioides. b, Vertical section of a conidioma. c, Conidia on PDA. Scales: a=1.0 mm, $\mathrm{b}=50 \mu \mathrm{m}, \mathrm{c}=20 \mu \mathrm{m}$.

floccose, consisting of aerial mycelia and submerged vegetative hyphae, rarely producing conidia. Conidiomata, ascomata, and sclerotia were absent. The colonies on the leaf were circular to irregular, light brown, and formed conidiomata on the surface and reverse side. The conidiomata were acervular, epidermal to peridermal, with setae, producing white to light pink conidia in masses. The setae were dark brown to black, $27.9 \sim 51.3 \times$ $3.0 \sim 4.7 \mu \mathrm{m}$, and septate. The conidiophores were hyaline to brown, and septate, and were formed from the upper cells of the conidiomata. The conidia were hyaline, 27.9 51.3 $\times 3.0 \sim 4.7 \mu \mathrm{m}$, aseptate, straight, smooth, ellipsoidal to cylindrical, and apex obtuse. The appressoria were $5.3 \sim 14.8 \times 4.1 \sim 8.0 \mu \mathrm{m}$, and clavate to irregular.

Based on these taxonomic properties, the strain SANK 21404 was identified as Colletotrichum gloeosporioides (Penz.) Penz. \& Sacc [4]. It has been deposited at the National Institute of Advanced Industrial Science and Technology, Japan, under the accession number FERM BP10309.

\section{Fermentation}

The culture of the strain Colletotrichum gloeosporioides SANK 21404 on an agar slant was inoculated into $30 \mathrm{ml}$ of sterilized seed medium consisting of glycerol $3.0 \%$, glucose $3.0 \%$, soluble starch $2.0 \%$, soybean meal $1.0 \%$, gelatin $0.25 \%$, yeast extract $0.25 \%, \mathrm{NH}_{4} \mathrm{NO}_{3} 0.25 \%$ in 100 $\mathrm{ml}$ Erlenmeyer flask. The flask was incubated on a rotary shaker at $23^{\circ} \mathrm{C}, 210 \mathrm{rpm}$ for 5 days. The seed culture $(2.0 \mathrm{ml})$ was transferred into two $500-\mathrm{ml}$ Erlenmeyer flasks containing $80 \mathrm{ml}$ of sterilized producing medium consisting of glycerol $5.0 \%$, potato $5.0 \%$, malt extract $0.5 \%$, yeast extract $0.5 \%$, and incubated on a rotary shaker at $23^{\circ} \mathrm{C}$, 210 rpm for 7 days.

\section{Isolation of Colletoic Acid}

The $\mathrm{Me}_{2} \mathrm{CO}(200 \mathrm{ml})$ was added to the harvested broth
$(160 \mathrm{ml})$ and the colletoic acid was extracted for 30 minutes. After centrifuging, the resulting supernatant was adjusted to $\mathrm{pH} 3.0$ with $6 \mathrm{M} \mathrm{HCl}$. The solution was extracted twice with EtOAc $(200 \mathrm{ml})$, and the upper layers were combined. The solvent layer $(500 \mathrm{ml})$ was washed with brine $(200 \mathrm{ml})$, dried over anhydrous $\mathrm{Na}_{2} \mathrm{SO}_{4}$ and concentrated in vacuo to dryness to yield an oily material $(188 \mathrm{mg})$. The material was dissolved in $10 \mathrm{ml}$ of $\mathrm{MeOH}$ $\mathrm{H}_{2} \mathrm{O}(2: 3)$ containing $0.3 \%$ triethylamine phosphate $(\mathrm{pH}$ 3.0) and was applied onto $50 \mathrm{ml}$ of an ODS column (Cosmosil 140 C18 OPN, Nacalai Tesque) which was equilibrated with $\mathrm{CH}_{3} \mathrm{CN}-\mathrm{H}_{2} \mathrm{O}$ (3:7) containing $0.3 \%$ triethylamine phosphate $(\mathrm{pH} 3.0)$. The adsorbed substance was eluted successively with $200 \mathrm{ml}$ of $\mathrm{CH}_{3} \mathrm{CN}-\mathrm{H}_{2} \mathrm{O}$ (30:70, 35:65 and 40:60) containing $0.3 \%$ triethylamine phosphate ( $\mathrm{pH}$ 3.0). An $\mathrm{CH}_{3} \mathrm{CN}-\mathrm{H}_{2} \mathrm{O}$ fraction in the ratio of 40:60 was collected, concentrated, and then the compound was extracted twice with EtOAc. The EtOAc layer $(500 \mathrm{ml})$ was dried over anhydrous $\mathrm{Na}_{2} \mathrm{SO}_{4}$ and concentrated in vacuo to dryness to yield an oily material $(14 \mathrm{mg})$. After the material was dissolved in $500 \mu \mathrm{l}$ of $\mathrm{MeOH}$, a $100-\mu 1$ portion of it was charged to the preparative HPLC (column; Capcell Pak C18 UG120, $20 \times 250 \mathrm{~mm}$, mobile phase; $\mathrm{CH}_{3} \mathrm{CN}-\mathrm{H}_{2} \mathrm{O} \quad(48: 52)$ containing $0.05 \% \mathrm{HCOOH}$, flow rate; $10 \mathrm{ml} / \mathrm{minute}$, detection; UV at $210 \mathrm{~nm}$ ). After preparations were performed 5 times, the active fractions were combined and evaporated under reduced pressure to remove the solvent, which was followed by freeze drying to give pure colletoic acid as a white powder $(7.4 \mathrm{mg})$.

\section{Physico-chemical Properties}

The physico-chemical properties of the colletoic acid are summarized in Table 1.

Colletoic acid was soluble in several organic solvents, including EtOAc, $\mathrm{MeOH}$ and DMSO. The UV spectrum showed end absorption. The IR absorptions at 3282 and 
Table 1 Physico-chemical properties of colletoic acid

\begin{tabular}{ll}
\hline $\begin{array}{l}\text { Appearance } \\
{[\alpha]_{D}^{25}}\end{array}$ & White powder \\
Molecular weight & $+17.8^{\circ}(c 0.73, \mathrm{MeOH})$ \\
Molecular formura & 252 \\
FAB-MS $(\mathrm{m} / \mathrm{z})$ & $\mathrm{C}_{15} \mathrm{H}_{24} \mathrm{O}_{3}$ \\
HRFAB-MS $(\mathrm{m} / \mathrm{z})$ & $275(\mathrm{M}+\mathrm{Na})^{+}$ \\
\multicolumn{1}{c}{ Found: } & \\
Calcd.: & 275.1633 \\
UV absorption (MeOH) & 275.1623 \\
IR $v_{\text {max }}^{\text {Thin film } \mathrm{cm}^{-1}}$ & End absorption \\
& $3282,2957,2877,2637$, \\
& $1687,1548,1450,1410$, \\
& $1392,1367,1308,1276$, \\
Solubility & $1256,1215,1193,1169$, \\
Soluble & $1100,1078,1053,1034$, \\
& $985,962,926$ \\
& EtOAc, MeOH, DMSO
\end{tabular}

$1686 \mathrm{~cm}^{-1}$ suggested the presence of a carboxyl group in the structure. The molecular weight was determined to be 252 by FAB-MS and the molecular formula was established as $\mathrm{C}_{15} \mathrm{H}_{24} \mathrm{O}_{3}$, which was calculated to have four degrees of unsaturation, from the results of the high resolution FABMS and additional data from the NMR studies.

\section{Structure Elucidation}

Planar Structure of Colletoic Acid The ${ }^{13} \mathrm{C}$ - and ${ }^{1} \mathrm{H}-\mathrm{NMR}$ data $\left(\mathrm{DMSO}-d_{6}\right)$ of colletoic acid are shown in Table 2.

The ${ }^{13} \mathrm{C}-\mathrm{NMR}$ data revealed the presence of three methyls, four $s p^{3}$ methylenes, four $s p^{3}$ methines, one $s p^{2}$ methine, one $s p^{3}$ quaternary carbon, one $s p^{2}$ quaternary carbon and one carbonyl carbon.

DQF-COSY, HSQC, ${ }^{1} \mathrm{H}-{ }^{13} \mathrm{C}$ HMBC and phase-sensitive 2D-INADEQUATE [5] studies in DMSO- $d_{6}$ were applied to elucidate the planar structure.

As shown in Fig. 3, INADEQUATE spectrum analysis allowed us all the $\mathrm{C}-\mathrm{C}$ bond linkages except for $\mathrm{C}-7$ to $\mathrm{C}-8$. Finally, the key $\mathrm{H}-\mathrm{C}$ long-range couplings between $\mathrm{H}-1$ to C-5/C-10 and H-4 to C-5/C-10 observed in the HMBC spectrum confirmed a bicyclo-ring system and correlations between $\mathrm{H}-7$ to $\mathrm{C}-9 / \mathrm{C}-15, \mathrm{H}-9$ to $\mathrm{C}-7$ and $\mathrm{H}-15$ to $\mathrm{C}-7$ followed by a DQF-COSY study clarified the propene system.

Thus, the planar structure of colletoic acid was elucidated as a novel acorene-type sesquiterpene.
Table 2 NMR spectral data of colletoic acid in DMSO- $d_{6}$

\begin{tabular}{|c|c|c|}
\hline Position & $\delta_{C}\left(\right.$ multiplicity $\left.{ }^{a}\right)$ & $\delta_{\mathrm{H}}$ (multiplicity, $J$ in $\mathrm{Hz}$ ) \\
\hline 1 & 55.2 (d) & $2.47(1 \mathrm{H}, \mathrm{t}, J=8.4 \mathrm{~Hz})$ \\
\hline 2 & $26.1(\mathrm{t})$ & $\begin{array}{l}1.69(1 \mathrm{H}, \mathrm{m}) \\
1.80(1 \mathrm{H}, \mathrm{m})\end{array}$ \\
\hline 3 & $23.7(t)$ & $1.58(2 \mathrm{H}, \mathrm{m})$ \\
\hline 4 & $55.2(d)$ & $1.50(1 \mathrm{H}, \mathrm{m})$ \\
\hline 5 & 47.1 (s) & \\
\hline 6 & $27.3(t)$ & $\begin{array}{l}1.88(1 \mathrm{H}, \text { br. d, } J=18.1 \mathrm{~Hz}) \\
1.94(1 \mathrm{H}, \text { br. d, } J=18.1 \mathrm{~Hz})\end{array}$ \\
\hline 7 & $122.6(d)$ & $5.34(1 \mathrm{H}$, br. s) \\
\hline 8 & 135.9 (s) & \\
\hline 9 & $66.8(d)$ & $3.99(1 \mathrm{H}$, br. t, J=6.5 Hz) \\
\hline 10 & $45.8(t)$ & $\begin{array}{l}1.78(1 \mathrm{H}, \mathrm{m}) \\
1.85(1 \mathrm{H}, \mathrm{m})\end{array}$ \\
\hline \multirow[t]{2}{*}{11} & 176.1 (s) & \\
\hline & & 12.07 (br. s) \\
\hline 12 & 27.1 (d) & $1.75(1 \mathrm{H}, \mathrm{m})$ \\
\hline 13 & $25.2(q)$ & $0.85(3 \mathrm{H}, \mathrm{d}, J=6.8 \mathrm{~Hz})$ \\
\hline 14 & $19.2(q)$ & $0.78(3 \mathrm{H}, \mathrm{d}, J=6.6 \mathrm{~Hz})$ \\
\hline 15 & $19.6(q)$ & $1.63(3 \mathrm{H}$, br. s) \\
\hline
\end{tabular}

The solvent signal was used for an internal standard as $\delta_{\mathrm{H}} 2.50$ and $\delta_{\mathrm{C}} 39.51$.

${ }^{a}$ Multiplicity by DEPT experiment
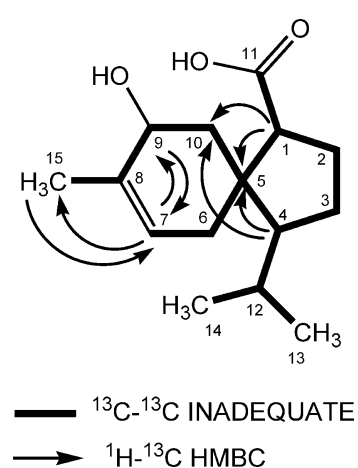

Fig. $3{ }^{1} J_{C-C}$ and key $\mathrm{H}-\mathrm{C}$ long-range couplings of colletoic acid.

\section{Stereochemistry of Colletoic Acid}

The absolute configuration of C-9 was determined by a modified Mosher's Method [6, 7]. Because the presence of carboxylic acid at $\mathrm{C}$-1 was not favorable for the application of this method, the carboxyl residue was esterified (Materials and Methods section). Treatment of the methyl ester derivative with $(R)-(-)$ - and $(S)-(+)-\mathrm{MTPA}-\mathrm{Cl}$ afforded the $(S)$ - and $(R)$-MTPA esters, respectively.

As shown in Fig. 4, differences in the chemical shifts of 


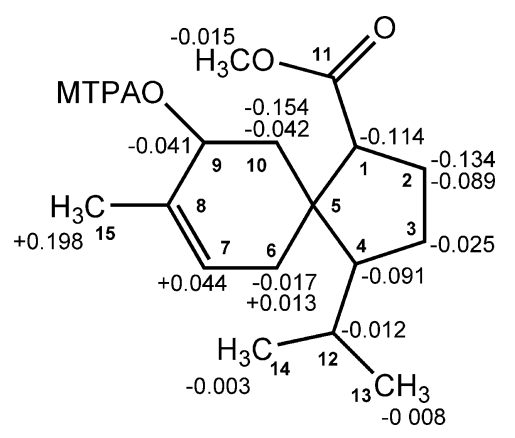

Fig. 4 Distribution of $\Delta \delta_{S-R}$ values of the (S)- and $(R)$ MTPA esters of colletoic acid methylester.

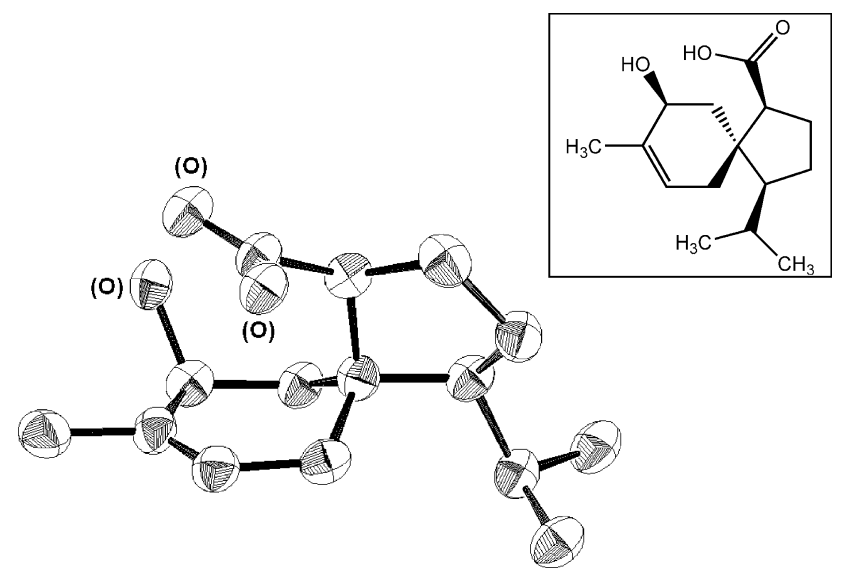

Fig. 5 An ORTEP drawing of colletoic acid.

each MTPA derivative $\left(\Delta \delta_{S-R}\right)$ at H-7 and H-15 showed significantly positive values, while those at $\mathrm{H}-1, \mathrm{H}-2, \mathrm{H}-3$, $\mathrm{H}-4$ and $\mathrm{H}-10$ were apparently negative clearly indicating that C-9 is an $S$-configuration.

Consequently, along with the relative configuration obtained by X-ray crystallographic analysis, the configurations of all four asymmetric carbons in colletoic acid were determined to be $S$.

Thus, the absolute structure of colletoic acid was elucidated as shown in the ORTEP drawing in Fig. 5.

\section{Biological Activities}

As shown in Table 3, colletoic acid potently inhibited human $11 \beta$-HSD1 activity in a dose-dependent manner with the $\mathrm{IC}_{50}$ value of $13 \mathrm{nM}$. However, colletoic acid weakly inhibited mouse $11 \beta$-HSD1 with the $\mathrm{IC}_{50}$ value of $460 \mathrm{nM}$, and did not inhibit its isoform of human $11 \beta$ HSD2. To analyse the $11 \beta$-HSD1 inhibition mechanism of colletoic acid, we performed kinetic analysis. The Lineweaver-Burk plots revealed that colletoic acid behaved as a competitive inhibitor of the human $11 \beta$-HSD1 (Fig. 6).
Table 3 Inhibitory activities of colletoic acid to $11 \beta$-HSDs

\begin{tabular}{cr}
\hline Enzyme & $\mathrm{IC}_{50}(\mathrm{nM})$ \\
\hline Human 11 $\beta$-HSD1 & 13 \\
Mouse 11 $\beta$-HSD1 & 460 \\
Human 11 $\beta$-HSD2 & $>10000$ \\
\hline
\end{tabular}

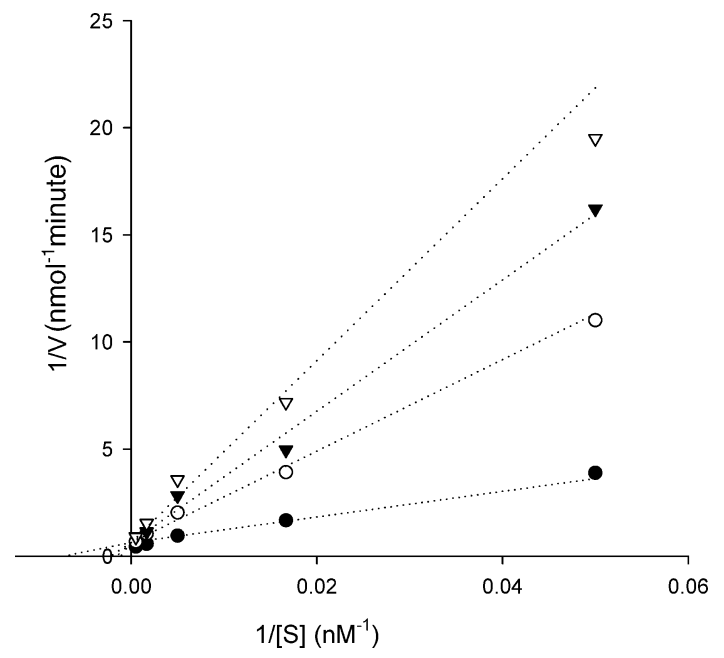

Fig. 6 Lineweaver-Burk plots for inhibition of human $11 \beta$ HSD1 by colletoic acid.

- None, $\bigcirc 8 \mathrm{nM}, \nabla 12 \mathrm{nM}, \nabla 27 \mathrm{nM}$.

The $K i$ value of colletoic acid was calculated to be $3.9 \mathrm{nM}$.

\section{Discussion}

In the present study, we have reported the discovery of a novel acorene-type sesquiterpene, named colletoic acid, in a cultured broth of the producing fungus, Colletotrichum gloeosporioides SANK 21404.

To date, various kinds of related sesquiterpenes have been reported [8]. Among them, the structures of 3hydroxy-4-acorene [9], alaskene and acoradiene from liverwort [10], tricho-acorenol from Trichoderma koningii [11], acorenones [12] and AC-1 through AC-4 [13] from rhizome of calamus (Acorus calamus), acorenone-B from Bothriochloa intermedia [14] were noted to be similar to that of colletoic acid. However, their planar structures were distinct from that of colletoic acid, which was fully oxidized to carboxylic acid at $\mathrm{C}-11$. Considering the stereochemistries of these acorene-type compounds, it is noteworthy that only acorenone-B possesses the same absolute structure as that of colletoic acid. Although 
acorenone-B was reported to be isolated from the plant, it is interesting that colletoic acid has the same configuration despite originating from a fungus. Since AC-4 was reported as a germination inhibitor of lettuce seeds, no further information about the activity of the others has been reported. Therefore, we determined whether the extract of Acorus calamus root possesses $11 \beta$-HSD1 inhibitory activity, but no activity was observed (data not shown). In addition, the methylester derivative of colletoic acid had no $11 \beta$-HSD1 inhibitory activity, suggesting that the carboxyl group plays a critical role in the inhibitory action. Although many other structurally similar acorene-type sesquiterpenes might be produced in the fermentation broth of the strain SANK 21404, we could not find any acoren-type compounds with inhibitory effects on $11 \beta$-HSD1 activity other than colletoic acid. These findings imply that the inhibitory properties of colletoic acid are strictly the result of its unique stereochemistry and the carboxyl group at C1. X-ray crystallographic analysis of its enzyme complex will be reported elsewhere.

Acknowledgements We are deeply grateful to Dr. Shuichiro Ito for his useful advice and support in the X-ray crystallographic analysis.

\section{References}

1. Kotelevtsev Y, Holmes MC, Burchell A, Houston PM, Schmoll D, Jamieson P, Best R, Brown R, Edwards CRW, Seckl JR, Mullins JJ. 11 $\beta$-Hydroxysteroid dehydrogenase type 1 knockout mice show attenuated glucocorticoidinducible responses and resist hyperglycemia on obesity or stress. Proc Natl Acad Sci USA 94: 14924-14929 (1997)

2. Masuzaki H, Paterson J, Shinyama H, Morton NM, Mullins JJ, Seckl JR, Flier JS. A transgenic model of visceral obesity and the metabolic syndrome. Science 294: 2166-2170 (2001)

3. Ito-Kobayashi M, Aoyagi A, Tanaka I, Muramatsu Y, Umetani M, Takatsu T. Sterenin A, B, C and D, novel $11 \beta$ hydroxysteroid dehydrogenase type 1 inhibitors from Stereum sp. SANK 21205. J Antibiot 61: 128-135 (2008)

4. Sutton BC. The genus Glomerella and its anamorph
Colletotrichum. In Colletotrichum: Biology, Pathology and Control. Ed., JA Bailey, MJ Jeger, pp. 1-26, CAB International, Wallingford (1992)

5. Bourdonneau M, Ancian B. Rapid-pulsing artifact-free double-quantum-filtered homonuclear spectroscopy: The 2D-INADEQUATE experiment revisited. J Magn Reson 132: 316-327 (1998)

6. Ohtani I, Kusumi T, Ishitsuka OM, Kakisawa H. Absolute configuration of marine diterpenes possessing a xenicane skeleton. An application of an advanced Mosher's method. Tetrahedron Lett 30: 3147-3150 (1989)

7. Ohtani I, Kusumi T, Kashman Y, Kakisawa H. High-field FT NMR application of Mosher's method. The absolute configurations of marine terpenoids. J Am Chem Soc 113: 4092-4096 (1991)

8. Connolly JD, Hill RA. Dictionary of Terpenoids. p. 597, Chapman \& Hall, London (1991)

9. Nagashima F, Suzuki M, Takaoka S, Asakawa Y. Sesquiand diterpenoids from the Japanese liverwort Jungermannia infusca. J Nat Prod 64: 1309-1317 (2001)

10. Warmers U, Konig WA. Sesquiterpene constituents of the liverwort Calypogeia fissa. Phytochemistry 52: 695-704 (1999)

11. Huang Q, Tezuka Y, Hatanaka Y, Kikuchi T, Nishi A, Tubaki K. Studies on metabolites of mycoparasitic fungi. III. New sesquiterpene alcohol from Trichoderma koningii. Chem Pharm Bull 43: 1035-1038 (1995)

12. Vrkoč J, Herout V, Šorm F. On terpenes. CXXXIII. Structure of acorenone, a sesquiterpenic ketone from sweet-flag oil (Acorus calamus L.). Coll Czech Chem Comm 26: 31833185 (1961)

13. Nawamaki K, Kuroyanagi M. Sesquiterpenoids from Acorus calamus as germination inhibitors. Phytochemistry 43: 1175-1182 (1996)

14. McClure RJ, Schorno KS, Bertrand JA, Zalkow LH. The structure and stereochemistry of a new sesquiterpene of the acorane type. Chem Commun 1135-1136 (1968) 